\title{
EFEK ANTI MIKROBA EKSTRAK BUNGA CENGKEH (SYZYGIUM AROMATICUM) TERHADAP METHICILLIN-RESISTANT STAPHYLOCOCCUS AUREUS (MRSA) SECARA IN VITRO.
}

\author{
Afaf Azizah ${ }^{1}$, Irma Suswati ${ }^{1}$, Sulistyo Mulyo Agustin ${ }^{1}$ \\ ${ }^{1}$ Fakultas Kedokteran, Universitas Muhammadiyah Malang \\ J1. Bendungan Sutami 188 A Malang, 65145
}

Email : afafazizah86@gmail.com

\begin{abstract}
ABSTRAK
Methicillin-Resistant Staphylococcus aureus (MRSA) merupakan salah satu bakteri penyebab infeksi, angka kejadiannya cukup tinggi. MRSA resisten terhadap beberapa antibiotik seperti beta-laktam(18\%), rifampisin (6,7\%), floroquinolon (84\%), linezolid (1,3\%) dan ampicillin (93,4\%). Ekstrak bunga cengkeh mempunyai efek antimikroba karena mengandung eugenol, flavonoid, tannin, saponin, alkaloid dan phenol yang dapat merusak struktur sel bakteri.Penelitian ini bertujuan untuk mengetahui efek antimikroba ekstrak bunga cengkeh (Syyygium aromaticum) terhadap MRSA secara in vitro.Metode yang digunakan experimental post test only group designdengan metode dilusi tabung berbagai konsentrasi ekstrak bunga cengkeh 0,39\%, 0,195\%, 0,097\%, 0,049\%, 0,024\%, 0,012\%, 0,006\%, 0,003\%. Analisis data menggunakan One Way Anova.Hasil penelitain menunjukkan Kadar Bunuh Minimal (KBM) adalah 0,39\%. Uji One Way Anova $\mathrm{p}=0,000(\mathrm{p}<0,05)$ menunjukkan terdapat perbedaan signifikan antara konsentrasi ekstrak bunga cengkeh dengan jumlah koloni MRSA. Ekstrak bunga cengkeh dapat membunuh MRSA dengan cara merusak struktur sel bakteri. Kesimpulan yang dapat ditarik adalah ekstrak bunga cengkeh (Syzygium aromaticum) mempunyai efek antimikroba terhadap MRSA secara in vitro.
\end{abstract}

Kata kunci : Ekstrak bunga cengkeh (Syzygium aromaticum), MRSA, KBM.

\begin{abstract}
Methicillin-Resistant Staphylococcus aureus (MRSA) is one of the bacteria that causes infections, the rate of occurrence is quite high. MRSA is resistant to several antibiotics such as beta-lactam (18\%), rifampicin (6.7\%), floroquinolone $(84 \%)$, linezolid $(1.3 \%)$ and ampicillin (93.4\%). Clove flower extract has an antimicrobial effect containing eugenol, flavonoids, tannins, saponins, alkaloids and phenols that can damage the structure of bacterial cells. Objective from this experiment is to find out the effect of antimicrobial clove flower extract (Syzygium aromaticum) against MRSA in vitro. The method used experimental post test only group design with tube dilution method various concentration of clove flower extract 0,39\%, 0,195\%, 0,097\%, 0,049\%, 0,024\%, 0,012\%, 0,006\%, 0,003\%. Data analysis used One Way Anova. The results showed that Minimum BactericidalConsentration $(\mathrm{MBC})$ was $0.39 \%$. One Way Anova test $\mathrm{p}=0.000(\mathrm{p}<0,05)$ showed significant difference between clove flower extract concentration and number of MRSA colonies. Clove flower extract can killed MRSA by damaging the structure of bacterial cells. The conclusion from this study is the clove flower extract (Syzygium aromaticum) has an antimicrobial effect on MRSA in vitro.
\end{abstract}

Keywords : clove flower extract (Syzygium aromaticum), MRSA, MBC 


\section{PENDAHULUAN}

Metbicillin-Resistant Staphylococcus aureus (MRSA) sering menyebabkan penyakit infeksi akibat tindakan invasif di rumah sakit (Nurkusuma DD, 2009). Beberapa penyakit yang disebabkan MRSA seperti pneumonia, selulitis, endokarditis, osteomyelitis, luka diabetes dan luka pasca operasi (Lin C, 2011). Di India, angka kejadian luka diabetes dengan MRSA positif di Departemen Mikrobiologi sebesar 69,8\% dan luka non diabetes sebesar 38,4\% (Rani $R V$, 2014). Sedangkan di RS Dokter Kariadi Semarang, luka pasca operasi dengan MRSA positif menunjukkan angka yang cukup tinggi yaitu sebesar 58,8 \% (Nurkusuma DD, 2009).

MRSA merupakan strain dari Staphylococcus aureus yang resisten terhadap meticillin dan lebih dari $80 \%$ isolat Staphylococcus aureus yang diteliti, resisten terhadap golongan antibiotik beta-laktam (EARS.2013). Annual Report of the European Antimicrobial (EARS.2013). Resistance Surveillance Network melaporkan bahwa beberapa antibiotik yang resisten terhadap MRSA dibeberapa negara seperti beta-lactam (18\%), rifampisin (6,7\%), floroquinolon (84\%) dan linezolid (1,3\%). Dan dari 30 sampel isolat Staphylococcus aureusditemukan 93.4\% telah resisten terhadap ampicillin dan $6.6 \%$ isolate kuman masih sensitif terhadap ampicillin

Dari data tersebut, MRSA resisten terhadap beberapa obat. Resisten antibiotik ini dikarena perubahan genetik yang disebabkan oleh paparan terapi antibiotik yang tidak rasional (Nurkusuma $D D$, 2009). Oleh karena itu, dibutuhkan suatu pengobatan alternatif tambahan seperti misalnya bunga cengkeh (Syzigium aromaticum) (Nurdjannah N. 2004). Bunga cengkeh memiliki beberapa manfaat sebagai analgesik, antiemetik, antijamur, antiseptik, antiinflamasi dan salah satunya sebagai antibakteri (Pramod, K 2010). Kemampuan bunga cengkeh sebagai antibakteri karena bunga cengkeh memiliki minyak atsiri yang mengandung eugenol, tanin, saponin, flavanoid, alkoloid dan phenol. Mekanisme antibakteri pada bunga cengkeh yaitu menyebabkan perubahan pada komponen makromolekul dari bakteri seperti merusak membran sel, membran protein inaktif secara irreversible dan menyebabkan kerusakan asam nukleat (Apriyani YM, 2015).

Penelitian sebelumnya menunjukkan ektrak bunga cengkeh dapat menghambat Escherichia coli, Proteus mirabilis, Klebsiella pneumonie pada konsentrasi
(KHM) $6,25 \mathrm{mg} / \mathrm{ml}$ dan dapat membunuh pada konsentrasi (KBM) $25 \mathrm{mg} / \mathrm{ml}$ pada Escherichia coli dan $50 \mathrm{mg} / \mathrm{ml}$ pada Klebsiella pneumoni (Oshomoh O E, 2015). Hasil penelitian pendahuluan ekstrak bunga cengkeh terhadap MRSAdidapatkan KBM pada konsentrasi $0,39 \%$, sedangkan KHM tidak dapat dinilai disebabkan ekstrak bunga cengkeh berwarna keruh atau coklat kehitaman, sehingga berpengaruh pada penilaian tingkat kejernihan.

\section{METODE PENELITIAN}

Desain penelitian initrue eksperimental, dengan menggunakan Post test only control. Metode yang dipakai adalah dilusi tabung (tube dilution test). Penelitian ini dilakukan pada bulan Februari 2017 selama \pm 1 minggu di Laboratorium Biomedik Fakultas KedokteranUniversitas Muhammadiyah Malang.Populasi yang dipakai bakteri MRSA biakan murni yang diperoleh dari Laboratorium Mikrobiologi Fakultas Kedokteran Universitas Brawijayamenggunakan simple random sampling.

Ekstrak bunga cengkeh dibuat dengan cara bunga cengkeh dicuci kemudian dikeringkan di bawah sinar matahari. Setelah kering bahan dihaluskan dengan blender sehingga didapatkan bentuk serbuk. Maserasi dimulai dengan cara menuangkan etanol $96 \%$ ke dalam wadah maserasi sampai seluruh serbuk terendam dan pelarut dilebihkan $\pm 2 \mathrm{~cm}$ di atas permukaan serbuk bunga cengekeh. Dalam penelitian ini digunakan pelarut etanol $96 \%$ karena etanol dapat mengangkat atau lebih memperkuat kandungan yang aktif pada bunga cengkeh. Bahan direndam dan ditutup selama 24 jam. Setelah 24 jam, lakukan penyaringan bahan dengan kain saring sampai tidak ada cairan yang menetes dari bahan. Cairan hasil penyaringan dipindahkan pada labu evaporator dan diletakkan pada evaporator.Proses evaporasi sampai volume kecil hasil ekstraksi berkurang dan menjadi kental. Hasil evaporasi kemudian ditampung dalam cawan panguap kemudian dioven selama \pm 2 jam pada suhu $80^{\circ} \mathrm{C}$ untuk menguapkan pelarut yang tersisa sehingga didapatkan hasil ekstrak bunga cengkeh $100 \%$.

Perbenihan cair bakteri dinilai absorbansinya dengan spektrofotometer pada gelombang cahaya $540 \mathrm{~nm}$. Dari nilai absorbsi dapat diperkirakan jumlah kuman pada perbenihan cair dengan kalibrasi yang sudah diketahui yaitu absobansi 0,1 ekuivalen 
dengan jumlah kuman sebesar $10^{8} \mathrm{CFU} / \mathrm{ml}$ (Murray $P$ R, 2013). Untuk mendapatkan suspensi dengan kepadatan $10^{8} \mathrm{CFU} / \mathrm{ml}$ sebanyak $10 \mathrm{ml}$ dibutuhkan $2 \mathrm{ml}$ suspensi awal untuk dicampur dengan $8 \mathrm{ml}$ Nutrient Brothsebagai pengencer. Setelah didapatkan perbenihan cair dengan jumlah kuman $10^{8} \mathrm{CFU} /$ $\mathrm{ml}$, dilakukan pengenceran dengan menggunakan Nutrient Broth sampai didapatkan perbenihan cair dengan jumlah kuman $10^{6} \mathrm{CFU} / \mathrm{ml}$.

\section{HASIL DAN PEMBAHASAN}

Berdasarkan penelitian yang telah dilakukan, KHM ekstrak bunga cengkeh tidak dapat dianalisis sebab tabung tampak keruh dikarenakan oleh kekeruhan ekstrak bunga cengkeh sedangkan KBM terdapat pada konsentrasi 0,39\% dengan hasil berupa penurunan jumlah koloni MRSA sampai 99,9\% dari kontrol kuman. Hasil penelitian tersebut menunjukkan semakin tinggi konsentrasi ekstrak bunga cengkeh menyebabkan semakin tinggi pula penurunan jumlah rata-rata koloni bakteri MRSA.

Efek antimikroba ekstrak bunga cengkeh terhadap MRSA belum pernah ada yang meneliti sebelumnya, tetapi sudah ada penelitian efek antimikroba ekstrak bunga cengkehterhadap beberapa Gram negatif, yaitu: P. mirabilis, E. coli dan K. Pneumoniae (Oshomoh O E, 2015). Dalam penelitian tersebut, KHM terdapat pada konsentrasi $6,25 \mathrm{mg} / \mathrm{ml}$ sedangkan KBM pada $P$. mirabilis sebesar $25 \mathrm{mg} / \mathrm{ml}$ dan KBM pada E. coli sebesar $50 \mathrm{mg} / \mathrm{ml}$. Perbedaan KHM tersebut dengan penulis dikarenakan ekstrak yang digunakan tidak keruh yang didapatkan dari metode ekstraksi dengan pelarut air, sedangkan penelitian penulis menggunakan metode maserasi dengan pelarut etanol sehingga berpengaruh pada penilaian tingkat kejernihan. Perbedaan hasil KBM penelitian sebelumnya, dengan hasil penelitian penulis dimungkinkan karena perbedaan kadar konsentrasi. Jika pada penelitian sebelumnya menggunakan konsentrasi50mg/ml, 25mg/ml, $12,5 \mathrm{mg} / \mathrm{ml}$ dan $6,25 \mathrm{mg} / \mathrm{ml}$ sedangkan pada penelitian penulis KBM ditemukan dengan konsentrasi $0,39 \%$ atau jika dikonversi menjadi $4 \mathrm{mg} / \mathrm{ml}$. Hasil tersebut menunjukkan bahwa ektrak bunga cengkeh memiliki efek antimikroba dengan konsentrasi yang terkecil pada MRSA dibandingkan E.coli dan P.mirabilis. Hal ini kemungkinan dikarenakan perbedaan dinding sel bakteri dimana bakteri MRSA merupakan bakteri gram positif yang hanya terdiri dari lapisan peptidoglikan dan asam teikoat dan juga mempunyai kandungan lipid yang rendah (1-4\%) sehingga memudahkan bahan bioaktif antibakteri masuk ke dalam sel sedangkan gram negatif memiliki 3 lapisan (lipoprotein, lapisan tengah, dan lipopolisakarida) dan mempunyai peptidoglikan dengan kandungan lipid yang tinggi (11-12\%) (Jawet2, 2013). Kandungan ekstrak bunga cengkeh yang kemungkinan berkaitan erat dengan dinding sel bakteri yaitu eugenol, flavanoid dan alkaloid. Selain dinding sel bakteri, pelarut ekstrak juga berpengaruh dalam menentukan KBM. Fungsi pelarut etanol sendiri untuk menarik lebih banyak kandungan zat aktif pada ekstrak bunga cengkeh dibandingkan pelarut air dikarenakan etanol mempunyai polaritas yang tinggi. Etanol juga mempunyai titik didih yang rendah dan cenderung aman, tidak beracun dan tidak berbahaya (Azis Tam₹il, 2014).

Hasil uji normalitas Shapiro Wilk didapatkan sig $\mathrm{p}>0.05$ sehingga menunjukan sebaran data normal, lalu dilanjutkan dengan uji homogenitas Levene didapatkan sig. $\mathrm{p}>0.05$ yang menunjukkan varian data homogen. Hasil penelitian penulis menunjukkan adanya perbedaan yang signifikan antara konsentrasi ekstrak bunga cengkeh denganjumlah koloni MRSAper cawan. Hal ini ditunjukkan dari hasil analisis One Way ANOVA dengan nilai signifikansi $\mathrm{p}<0.05$ yaitu $\mathrm{p}=$ 0.000.Untuk mengetahui konsentrasi ektrak bunga cengkeh mana saja yang berbeda secara bermakna pengaruhnya terhadap jumlah koloni, maka dilakukan uji post hoc (Bonferroni). Hasil uji post hoc (Bonferroni) didapatkan perbedaan jumlah koloni percawan yang signifikan sudah tampak pada konsentrasi $0,39 \%$ hingga $0,003 \%$ dibandingkan konsentrasi $0 \%$.

Efek antimikroba pada bunga cengkeh disebabkan karena bahan-bahan aktif yang terkandung di dalamnya, yaitu eugenol, tanin, saponin, flavonoid, fenol dan alkaloid. Keenam bahan tersebut dapat mempengaruhi strukturMRSA. Eugenol merupakan senyawa hidrofobik yang dengan mudah melewati dan merusak dinding sel bakteri gram negatif yang memiliki konsentrasi lipid yang tinggi (Maryati, 2007). Tanin memiliki aktivitas antibakteri yang berhubungan dengan kemampuannya untuk menginaktifkan adhesi sel mikroba, menginaktifkan enzim, dan menggangu 
transport protein pada lapisan dalam sel. Tanin juga mempunyai target pada polipeptida dinding sel sehingga pembentukan dinding sel menjadi kurang sempurna. Hal ini menyebabkan sel bakteri menjadi lisis karena tekanan osmotik maupun fisik sehingga sel bakteri akan mati (Smullen J., 2007). Saponin dapat menjadi antibakteri karena zat aktif permukaannya mirip detergen, akibatnya saponin akan menurunkan tegangan permukaan dinding sel bakteri dan merusak permeabialitas membran. Rusaknya membran sel ini sangat mengganggu kelangsungan hidup bakteri (Sirait, M. 2007). Flavonoid memiliki aktivitas antibakteri dalam melawan bakteri gram positif maupun gram negatif. Aktivitas flavonid diduga disebabkan oleh aktivitas gugus alkohol senyawa flavonoid yangmengikat peptidoglikan di dinding sel, selain itu gugus alkohol flavonoid juga mampu merusak membran sel bakteri melalui pengikatan pada lipopolisakarida Jawets, 2013). Mekanisme antibakteri fenol dalam membunuh mikroorganisme yaitu dengan mendenaturasi protein sel. Ikatan hidrogen yang terbentuk antara fenol dan protein mengakibatkan struktur protein menjadi rusak (Ahmed, Bahar 2007). Mekanisme antibakteri alkaloid yaitu komponen alkaloid diketahui sebagai interkelator DNA dan menghambat enzim topoisomerase sel bakteri (Karou, 2005). Bahan aktif tersebut, mana saja yang spesifik memberikan pengaruhterhadap pertumbuhan bakteri MRSA belum diteliti.

Faktor yang mampu mempengaruhi pertumbuhan MRSA terdiri dari faktor internal yaitu sensitivitas bakteri tersebut, yaitu sifat dari bakteri itu sendiri mengenai seberapa sensitif atau bahkan resisten terhadap paparan ekstrak. Salah satu faktor eksternal yang mampu mempengaruhi penelitian ini yaitu tingkat keasaman media kultur $(\mathrm{pH})$, suhu, cahaya dan aktivitas air. Kondisi pH sangat penting untuk pertumbuhan bakteri karena enzim tertentu hanya akan mengurai nutrisi sesuai aktivitasnya pada $\mathrm{pH}$ tertentu. Derajat keasaman $(\mathrm{pH})$ yang optimal pada media kultur dibutuhkan agar tidak menjadi perancu pada uji efek antimikroba. $\mathrm{pH}$ yang optimum untuk pertumbuhan MRSA yaitu 7,4 dan suhu optimum untuk pertumbuhan MRSA adalah $37^{\circ} \mathrm{C}$. Faktor suhu sudah diminimalisir dengan penggunaan inkubator yang suhunya akan stabil pada suhu optimal bagi pertumbuhan MRSA. Cahaya juga merupakan faktor yang berperan dalam mempengaruhi pertumbuhan
MRSA yang sudah diminimalisir pula dengan penggunaan inkubator (Vasanthakumari, R, .2007).

Keterbatasan dari penelitian ini adalah KHM yang tidak dapat ditentukan dikarenakan kekeruhan ekstrak bunga cengkeh sehingga tabung tampak keruh. Keterbatasan lain yaitu metode maserasi dengan pelarut etanol yang tidak mampu mengeluarkan zat aktif spesifik pada bunga cengkeh (isolasi zat aktif).

\section{KESIMPULAN}

1. Ekstrak bunga cengkeh (Syzigium aromaticum) mempunyai efek antimikroba terhadap MRSA secara in vitro

2. KBM ekstrak bunga cengkeh (Syzigium aromaticum) terhadap pertumbuhan MRSA adalah 0,39\%.

\section{DAFTAR PUSTAKA}

Ahmed, Bahar 2007. Chemistry Of Natural Products. New Delhi.Department of Pharmaceutical Chemistry Faculty of Science Jamia Hamdard

Apriyani YM, Priani SE, Gadri A, 2015, Aktivitas Antibakteri Minyak Batang Kayu Manis (Cinnamomum burmanni Nees Ex Bl) terhadap Bakteri Propionibakterium acnes, Prosiding Penelitian SPeSIA Unisba, 348-353

Azis Tamzil, Febrizky Sendry, Mario AD. 2014. Pengaruh Jenis Pelarut Terhadap Persen Yieldalkaloid dari Daun Salam India (Murraya koenigii). Jurusan Teknik Kimia, Fakultas Teknik, Universitas Sriwijaya. No. 2, Vol. 20, April 2014

EARS.2013. Antimicrobial Resistance Surveillance in Europe. Stockholm: ECDC; Europa. pp 5961

Jawetz, Melnick, \& Adelberg's. 2013. Medical Microbiology Twenty-Seventh Edition. McGrawHill Companies. US

Joshi B, Sah GP, Basnet BB, et al. 2011. Phytochemical extraction and antimicrobial propertiesof different medicinal plants: Ocimum sanctum (Tulsi),Eugenia caryophyllata (Clove), Achyranthes bidentata (Datiwan) and Azadirachta indica (Neem). Journal of Microbiology and Antimicrobials Vol. 3(1), pp. 1-7 
Karou, Damintoti. Savadogo Aly. 2005. Antibacterial activity of alkaloids from Sida acuta. African Lournal of Biotechnology. 4(12): $1452-1457$

Liu C, Bayer A, Cosgrove SE, et al. 2011. Clinical Practice Guidelines by the Infectious Diseases Society of America for the Treatment of MethicillinResistant Staphylococcus Aureus Infections in Adults and Children. Clinical Practice Guidelines: 52 pp 1-38

Maryati, Fauzia SR, Rahayu T. Uji aktivitas antibakteri minyak atsiri daun kemangi (Ocimum basillum L.) terhadap Staphylococcus aureus dan Escherichia coli. Jurnal Penelitian Sains \& Teknologi. Vol. 8, No. 1, 2007; 30 - 38.

Murray P R, Rosenthal S K, Pfaller A M. 2013. Medical Microbiology 8 Edition. Elsevier Health Sciences. Canada p.334-336

Nurdjannah N. 2004. Disferifikasi Penggunaan Cengkeh. Bogor: Balai Besar Penelitian dan Pengembangan Pasca Panen Pertanian. Perspektif vol 3: Hal 61-70

Nurkusuma DD, 2009, Faktor Yang Berpengaruh Terhadap Kejadian Methicillin-Resistant Staphylococcus Aureus (MRSA) Pada Kasus Infeksi Luka Pasca Operasi Di Ruang Perawatan Bedah Rumah Sakit Dokter Kariadi Semarang, Phd Thesis, Universitas Diponegoro, Semarang.p 44-48

Oshomoh O E, Idu M, Udinyiwe O C. 2015. Phytochemical Screening and Antimicrobial Sensitivity of Clove Flower (Syzygium aromaticum, L. Merrill and Perry) Bud on Dental Pathogens. Ijppr.Human, 2015; Vol. 3 (2): 1-13.

Pramod, K., S.H. Ansari and J. Ali. 2010. Eugenol : a natural compound with versatile pharmacological actions. Natural Product Communications 5(12) : 1999-2006.p 12

Rani RV, Nithyalakshmi J. 2014. A comparative study of Diabetic and Non-diabetic wound infectionswith special reference to MRSA and ESBL. IJCMAS: Volume 3 Number 12 (2014) pp. 546-554

Sirait, M. (2007). Penuntun Fitokimia Dalam Farmasi. Bandung: Penerbit ITB. Hal. 158159

Smullen J., Koutsou, G. A., Zumbe, A. \& Storey, D. M., 2007, The Antibacterial Activity of Plant Extracts Containing Polyphenols Against Streptococcus mutans, Caries Res.,41, 342-349
Triana D. 2014. Frekuensi â-Lactamase Hasil Staphylococcus aureus Secara Iodometri Di Laboratorium Mikrobiologi Fakultas Kedokteran Universitas Andalas. Jurnal Gradien Vol. 10 No. 2 Juli 2014 : 992-995

Vasanthakumari,R .2007. Textbook of Microbiology New Delhi: BI Publications

WHO.2014. Antimicrobial Resistance Global Report on Surveillance. June ed.France: WHO Press.p 10-21 